\title{
Commuting Patterns of Workers in a Village of Barddhaman District, West Bengal
}

Bhaswati Mondal ${ }^{\dagger}$

\begin{abstract}
Commuting helps to keep balance between residence and workplace of workers. With growing accessibility and connectivity, the importance of commuting is increasing all over the world. It is becoming a major substitute to migration. In commute-studies, commute-pattern is an important chapter. It highlights commuters' directions of movement, distance they cover, modes of transport they use, the time they take to commute, etc. Unlike the urban-based commute pattern, commute pattern in rural areas are relatively an under-researched issue. In fact, traditionally rural people are thought to carry a sedentary lifestyle. Using primary data, this study aims to explore the commute patterns of rural workers located in the village of Gandharbapur of Barddhaman district of West Bengal, India. All the commuters were found to be engaged in non-farm work. Commuters stem from two major groups. One group of commuters is accumulated farm-income induced. They possess sufficient agricultural land. Investing their surplus farm-income, they have established non-farm works. The second group of commuters is poverty-driven. They are landless poor or are marginal farmers and to escape poverty, they have slipped into these works. Located beyond the suburban area (Memari being the nearest town), most commuters commute to nearby rural areas. Due to non-availability of public transport, women commute less than men do. Regular-paid government employees commute longer than other workers commute. The article concludes with a summary of findings and recommendations for further research.

Key words: Commuting, Working Commuters, Commuting Patterns, Rural area, Barddhaman District, West Bengal, India
\end{abstract}

\footnotetext{
†Junior Research Fellow (UGC), Department of Geography, The University of Burdwan West Bengal-713104,Email: bhaswatimondal11@gmail.com

(C)2015 Mondal. This is an Open Access article distributed under the terms of the Creative Commons Attribution License (http://creativecommons.org/licenses/by/2.0), which permits unrestricted use, distribution, and reproduction in any medium, provided the original work is properly cited.
} 


\section{Introduction}

Commuting is a significant form of spatial mobility. In contemporary literature, commuting has been explained in a number of ways. The act of commuting necessarily entails daily reversible movement but on the bases of time and distance it involves, there are diverse views among scholars. Actually, scholars have dealt with these two parameters according to their study area and research design (Mahbub, 1997). Commuting is the interplay between residence and workplace over a day. It is determined by an equilibrium state of housing and labour market, in which individual's wellbeing or utility is equalized over all combinations of alternatives in these two markets' (Stutzer and Frey, 2007:1). It allows workers to link their workplaces spatially with their residence on a day-to-day basis (Ommerenet al., 1997). With the improvement of accessibility and connectivity, commuting is becoming an important substitute to migration in most parts of the world (Mahbub, 1997; Deshingkar and Anderson, 2004; Klis and Mulder, 2008; Statistics New Zealand). Unlike the issue of migration, which has been studied in depth, commuting is a relatively under researched issue, especially in the context of developing countries. The literature on commuting is enriched with empirical studies from developed countries where workers commute from suburbs to city centre (Renkow and Hoover, 2000). Developed countries have shown interest to enumerate the commuters, their economy, directions of commuting, etc. (Partridge et al., 2010; Champion et al., 2009; Chen et al., 2010). It is crucial for regional developmental policies, transport planning and management, environmental policies, etc. In developing countries like India, there is no record of the people who are on the move. In this article, commuting has been represented to refer to the daily spatial oscillation of workers across the village-administrative boundary for their main work. ${ }^{1}$

\footnotetext{
${ }^{1}$ The work in which workers are engaged at least for six months in a year (Census of India, 2011).
}

Commuting helps workers to integrate internal home-sphere to external workspace. It 'plays a causal role in the process of adjusting between residence and workplace' (Punpuing, 1993: 527). Thus, participation in workforce does not divert commuters from household duties. Commuting workers are significant because they stay in one place and work in another place. For the accomplishment of this purpose, they move between the place of residence and place of work daily (Chandrasekhar, 2011). This daily journey-to-work gives rise to a spatial pattern, which is determined by the location of housing, workplace and the transport mode used (Chen et al., 2010). Besides these three major factors, a number of other factors such as geographic factors (distance, physiography, climate, etc.), demographic factors (age, gender), socio-economic factors (occupation, income, economic agglomeration and diversification of the two areas, development criteria), etc. also determine the commute patterns. Commute pattern is expressed in terms of directions of commute, commute time, commute costs, commuters' modes of transport, etc. Previously, commuters' major destinations were the urban areas. In recent years, with the development of polycentric growth points in the form of small and medium towns, census towns and rural service centres, commute pattern is changing (Clark et al., 2003; Morrill et al., 1999). Now-a-days, rural-to-rural, urban-to-rural, urban-to-urban commuting is also popular along with rural-to-urban commute trips.

Commuting of rural workers is rapidly increasing as a result of increasing trend of nonfarm work (Reardon et al., 2007), improved access to work, transport and information technology, improvement of academic level and exposure, growth of small-medium towns and rural service centres (Partridge et al., 2010), and also for the degradation of common property resources in the villages which creates rural joblessness and push people to commute outside (Deshingkar and Anderson, 2004), and for the development-related displacement from cities (Kundu, 2009). As commuting does not entail a change of residence, most 
demographers tend to exclude it from mainstream mobility studies (Punpuing, 1993). Planners propose policies considering people sedentary. Official databases do not incorporate the seasonal movers, circular migrants and commuters, which involve many more people than permanent migrants do (Deshingkar, 2010). So many people survive depending upon the place beyond the place of their residence. A record of this kind would facilitate rural development planners who propose a number of in-situ proposals. Skeldon (1984, quoted in Mahbub, 1997: 32), in this context, made a remarkable comment: '[i]f only the longer distance flows are considered as migration, the population of South Asia appears relatively immobile but the whole situation changes if the local movers are included'. Although some think commuting as an urban phenomenon, rural-to-rural commuting is more complex and multidimensional (Harris et al., 2008). Rural-to-urban commuting is one of the key components of rural-urban integration. Population of rural areas may grow without the growth of local job centres, and thus a broad regional economy is developed. Some rural areas are located far from the urban shadow. With increasing distance from urban centres, the rate of rural-to-urban commuting lowers down (Vaidyanathan, 1986). As opposed to the peri-urban villages, inter-rural commuting is more prominent there.

\section{Objectives}

In 'the geography of commuting' (Dickinson, 1957), commute pattern is an important dimension. It shows commuters' directions of movements, distance they cover daily, the time they take to commute, types of transit they depend on and the costs associated with these. Some of these variables are interrelated and inter-dependent. For example, commute time depends on distance to be travelled and transittype. In India, commute pattern has been studied at the national and at regional levels. The national level study (Chandrasekhar, 2011) focuses the nation as a whole with some state level differences while the regional-level studies are fitted in major metropolitans and their suburbs (Tiwari and Kawakami, 2001, on commuters' modes in Mumbai; Srinivasan et al., 2007, in Chennai; Reddy and Balachandra, 2012, in megacities of India; Sabapathy et al., 2012, on commute patterns of employees in Information Technology and traditional manufacturing sectors of Bangalore; Shirgaokar, 2014, on work commute flows of Mumbai). Beyond these metropolitan-level studies, there is no such significant research on commute pattern available in contemporary social science literature in India. There is a gap in research. However, with the emergence of multi-nodal growth points in the form of small and medium towns, census towns, rural service centres and large villages, the traditional picture of commute pattern are changing. Rural people's (even those who reside beyond the shadows of the suburbs) commuting for works are increasing all over the world, be it developed (Harris et al., 2008; Partridge et al., 2010) or developing countries (Mahbub, 1997). Harris et al. (2008), in this context, commented that rural-to-rural commuting is more complex and multidimensional. Unlike the metropolitan commute pattern, it is relatively an underresearched issue.

This research aims at exploring the rural workers' commute pattern in the village of Gandharbapur located in the Barddhaman district of West Bengal, India. This research shows the commuters' directions of movement, distance they commute, transport mode they use and the time they take to commute. Since these variables are often guided by a number of socio-economic and socio-demographic variables such as age, gender, occupation, land holdings, occupancy of vehicle, these have also been discussed in relation to the parameters of commuting. Besides, local infrastructural development in terms of road and public transit, which play important roles in promoting commuting, have also been discussed. This study involves both men and women commuters. It shows that women are more dependent on public transit than men are. Due to absence of frequent plying of public transit, women commute much less, than their counterparts do. Thus in spite of having the 
ability and willingness to take part in earning, women's mobility remains restricted. In this respect, the importance of paratransit in rural transport has been mentioned. In this research, it was found that one group of commuters are distress-driven while another group is surplusincome induced. Commute time is closely linked to commuters' income. Higher the per capita incomes, more the access to motorised transport commuters have. Finally, based on these findings, it carves out future research agenda.

\section{Data and Methods}

This research is based on both primary and secondary data. For understanding the overall socio-demography and economy of the study area, Census data of 2011 were followed. It outlines total population size, sex ratio, literacy rate, total area of the village, area under cultivable land, workforce share in different categories of occupations, etc. In addition, it also paints the percentage figure of working people at block-district-state and national levels. There is very limited secondary data available on commuting in India. Primary data were collected in two phases-in April 2014 and in the first week of February 2015. The empirical study is based on a total enumeration of 60 working commuters. Only those persons have been identified as working commuters who live in this village permanently and cross their village administrative boundary regularly for their main economic activities and return on the same day. This includes only the main workers. $^{2}$ Therefore, seasonal commuters and student commuters were excluded from this study. The data were collected using semistructured survey-schedules as well as via informal interviews. Commuters were asked about their age, family type, academic qualification, occupation, commute distance (kilometre), commute time, mode of travel, income, land ownership, etc. Besides the commuters, few non-commuters were also interviewed. This group of non-commuters

\footnotetext{
2 Those who work for the major part of the reference period ( 6 months or above in a year) are called main workers (Census of India, 2011).
}

consists of few farmers from whom data about the soil-fertility, agricultural productivity, major crops and the labour-wages were known to comprehend the farm-economy well and also, few women who willingly wanted to take part in this interview to narrate their helpless situation because of the absence of regular and frequent public transit. After collecting the data, it was found that there are two groups of commuters. One group is in remunerative jobs while another group belongs to nonremunerative jobs. Few selected participants from both the groups were interviewed in depth to gather an idea of the process of acceptance of these non-farm works. In the second phase of data collection, which was conducted in February 2015, narratives were taken from an earlier commuter participant whose mobility has been restricted for poor health and absence of paratransit. Both quantitative and qualitative methods were employed to analyse the data. Descriptive statistics, correlation, cartograms have been prepared using MS-Excel 2010 to represent commuters' age, gender biasness, occupational profile, distance and direction of commuting, to establish relation between absolute physical distance and time distance. The location map has been prepared using Maplnfo Professional 7.0. Commuting distance has been measured along the detours. To convey the villagers' helpless situation, their anxiety and irritation because of the absence of good road and public transit, narratives have been used. A number of literature have been followed to develop the ideas and also to enrich the empirical evidences. The next section discusses the study area.

\section{The Study Area}

The area selected for executing the study is a small village named Gandharbapur (village code 320381 in 2011 Census) located in Memri-II Block of Barddhaman District in West Bengal (please see Figure 1). The village-boundary corresponds to the mouza-boundary (J.L. No. 119). Gandharbapur is located in between $23^{\circ} 12^{\prime} 30^{\prime \prime} \mathrm{N}$ to $23^{\circ} 13^{\prime} 45^{\prime \prime} \mathrm{N}$ latitude and $88^{\circ} 06^{\prime} 15^{\prime \prime} \mathrm{E}$ to $88^{\circ} 07^{\prime} 15^{\prime \prime} \mathrm{E}$ longitude covering an 
area of 188.36 hectare or 1.884 sq. kilometres. The village has been included in the Toposheet $79 \mathrm{~A} / 4(1: 50,000)$ published by the Survey of India. River Behula demarcates its eastern boundary. Villages all around circumscribe this village. In fact, Memari-II Block is a rural block without any urban centre. The nearest town
Memari is located about 10 kilometres away from this village. It is a medium-sized town and a block-headquarter. The village is about 35 kilometres away from Barddhaman, the district headquarter. Nearly $72 \%$ of the village-area is under cultivation. Here agricultural lands are very productive and well irrigated.

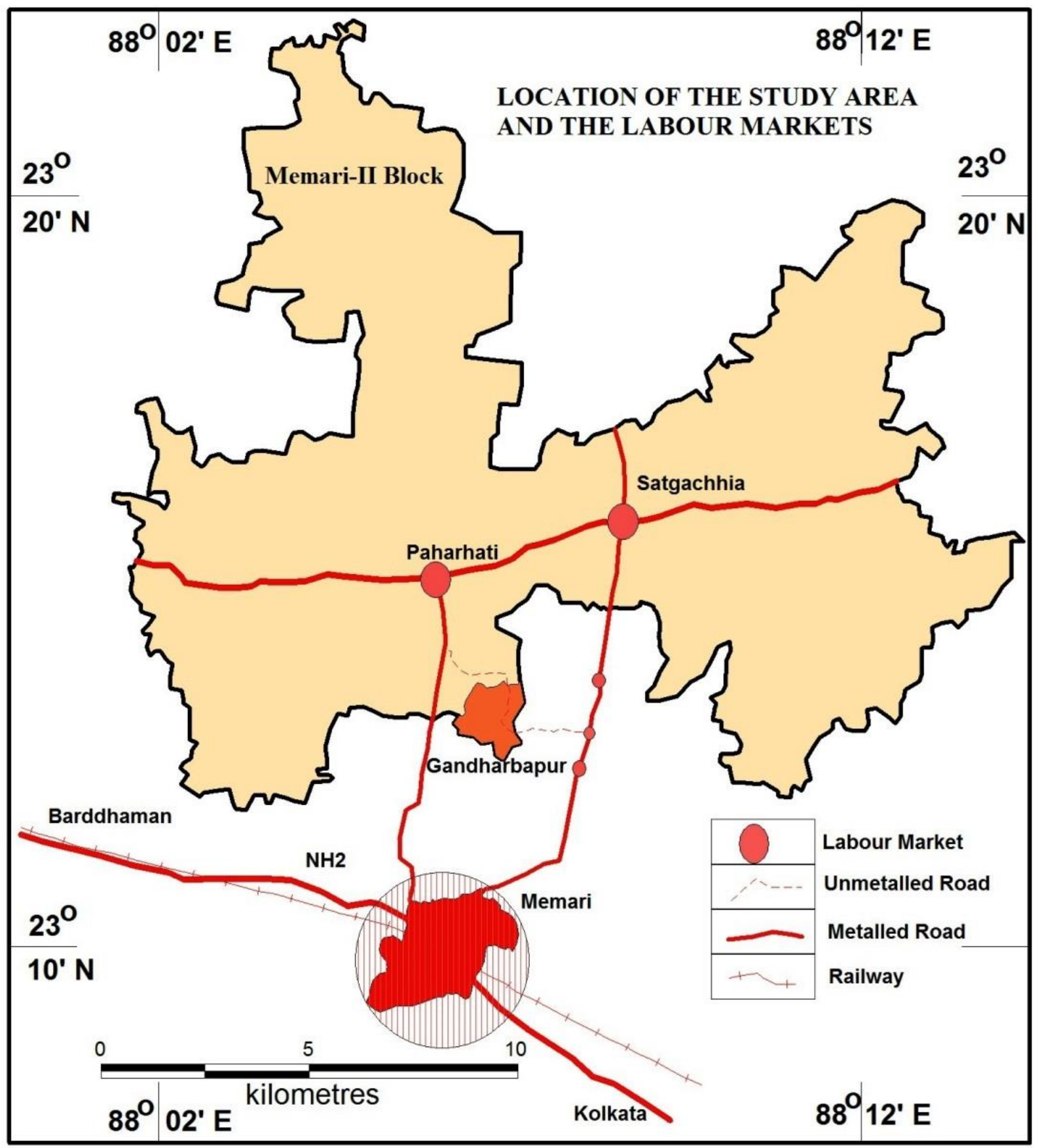

Figure 1

Source: Author 


\section{Table 1: Work Participation Rates at Different Administrative Levels, 2011}

\begin{tabular}{|l|l|l|l|l|l|l|l|l|}
\hline & Village & C.D. Block & \multicolumn{2}{|l|}{ District } & \multicolumn{2}{|l|}{ State } & \multicolumn{2}{l|}{ Country } \\
\hline & & & Tota1 & Rural & Total & Rural & Total & Rural \\
\hline $\begin{array}{l}\text { Work } \\
\text { Participation } \\
\begin{array}{l}\text { Rate (above 6 } \\
\text { yrs. age) in \% }\end{array}\end{array}$ & 54.24 & 47.88 & 42.28 & 45.29 & 45.66 & 46.57 & 47.80 & 49.98 \\
\hline $\begin{array}{l}\text { \% of Main } \\
\text { workers }\end{array}$ & 48.57 & 71.54 & 74.43 & 71.51 & 70.15 & 67.08 & 70.69 & 67.20 \\
\hline
\end{tabular}

Source: Computed from Census of India, 2011

Most of the lands are triple cropped. Paddy and potato are the two major crops. Total population is 1223 , which lies within size iii category, that is, in between 1000-1999 population class of inhabited villages. ${ }^{3}$ Sex ratio is 932 , which is much lower than at the rural national level i.e. 949. Nearly $74 \%$ of the population (above 6 years age) are literate. There is inadequate transport network provision. As one approaches from the town towards the village, the road worsens farther. The Pradhan Mantri Gram Sadak Yojana (PMGSY) ${ }^{4}$ has not been started yet in this village. The village road is still unmetalled. There is no provision of public transit. Villagers have to cross 4 kilometres of unmetalled road to access metalled road and public transit. The nearest railway station, Memari is also (10 kilometres away) on the Howrah-Barddhaman Main Line.

Work participation rate (above 6 years of age group) is $54 \%$, which outnumbers the block level, district level, state level and national level workforce participation rates. However, the significant difference is that most of the

\footnotetext{
${ }^{3}$ Census of India classifies inhabited villages in seven groups on the basis of broad population ranges, viz., (i) less than 200, (ii) 200-499, (iii) 500-999, (iv) 1000-1,999, (v) 2000-4,999, (vi) 5000-9,999, (vii) 10,000 and above. This classification corresponds to table A-3 of 2001, 1991, 1981, 1971, 1961 and 1951 census (Census of India, 2011).

${ }^{4}$ PMGSY is a nationwide plan in India to provide allweather good roads to all unconnected villages. It is under the Ministry of Rural Development, Government of India. It was launched in 2000 and still continuing its work (Pradhan Mantri Gram Sadak Yojana, 2015).
}

workers at block level, district level, state level and national level are in main work while in this village, less than $50 \%$ workers are in main work (Table 1). More than half of the total workers are engaged as marginal agricultural labourers. ${ }^{5}$ Again, of the total main workers, more than $70 \%$ are engaged in agriculture either as cultivators or as labourers. The overall ratio between cultivator and agricultural labourers is 9:41. Other than the agricultural workforce, the remaining main workers are in the census-defined 'other' occupation category $^{6}$ and less than $1 \%$ in household industry. $30 \%$ of main workers are engaged in non-farm works, both organised and unorganised sectors. Within this non-farm work category, more than $71 \%$ of workers commute to other villages and towns for work because there is very limited opportunity of non-farm work. All commuters of this village are found to be engaged in non-farm works be it organised or unorganised. ${ }^{7}$

\footnotetext{
${ }^{5}$ Marginal workers are those workers who work less than six months in a year (Census of India, 2011).

${ }^{6}$ Workers other than cultivators, agricultural labourers and household industry workers.

${ }^{7}$ In this article, the concept of organised-unorganised jobs have been explained following National Commission for Enterprises in the Unorganised Sector (NCEUS, 2007 quoted in Mehrotra et al., 2012:6-8). The NCEUS defines 'organised' and 'unorganised' on the basis of various factors including enterprise type, number of workers and social benefits. All enterprises under the domain of government/public sector, public/pvt. Itd. Companies, co-operatives, trusts are considered as organised sectors. Even if the enterprise is not known and it gives employment to more than 10 persons, it is considered to be an organised sector. The unorganised (non-farm)
} 
There are both long-distance commuters as well as short-distance commuters. The author was familiar to the villagers. This village was selected so that the author can do total enumeration in details.

\section{Demographic Details}

Since this study covers only the working commuters (both men and women), their age is distributed over working age group. Among the participants, the youngest one is of 17 years old. The lower limit of age is much lower because of the incidence of dropout of students from schools and their early engagement in earning. The oldest one is of 65 years old. The calculated range of the commuters thereby stands at 48 years. The median age of all commuters in this village is 40 years. This finding is similar to the findings of the median age of working commuters in rural Bangladesh, which was calculated as 39 years (Mahbub, 1997:117) and to the Pittsburgh Downtown area where maximum number of commuters fall within the age range of $36-45$ years (Pittsburgh Downtown Partnership, 2010). Rural workers above 35 years of age tend to commute more. It is for two basic reasons. First, most of them are married and by commuting, they can maintain both household responsibilities as well as the workspace commitments. Second, they can look after the farm-activities along with their non-farm jobs (Mahbub, 1997).

There is sharp gender disparity among commuters in this part of rural arena. Men dominate in commuting over the women. It was found that nearly $92 \%$ of all commuters are men. It will not be right to think that women's work participation in this village is low. Of total workers, nearly half are women (Census of India, 2011). However, most women (77\%)

sector, on the other hand, consists of all incorporated private enterprises owned by individuals or households engaged in the sale and production of goods and services operated on a proprietary or partnership basis and with less than ten total workers. Although the financial output generating capacity of organised sector far exceeds the unorganised sector jobs, in rural India, the concentration of unorganised sector jobs is more than organised sector jobs. work as marginal agricultural workers. Most time they are confined within household chores and work as additional earning members in peak agrarian season. In fact, traditionally women are habituated to see themselves as secondary wage earners (White, 1977). Women are more likely to be part time jobholders (Littlefield and Nash, 2008; Mathew, 2012; Higgins et al., 2000; Srivastava and Srivastava, 2009; Coppard, 2001). Women working throughout the year are few in number in this village. $29 \%$ of such women are in non-farm works (main) and of them, 38\% commute for work. All women commuters are in different government and non-government jobs like teaching in government-run primary and secondary schools and working in health centres. This is a significant finding to argue that women workers commute only for regular paid white-collar jobs, which require qualifications and academic skills. All the women commuters were found to have at least $12+$ qualifications. This finding is analogous to Moss et al. (2004:134) who found most women commuters of rural Northern Ireland in regular paid-public sector jobs, especially in the field of education and health.

Non-availability of non-farm jobs nearby, long distance from urban centre, absence of good road and public transport, low attainment of higher education, lack of exposure and traditional attitude towards women in the society are found to be primary reasons for less number of women commuters. As the distance from urban centre increases the density of transport network decreases (Littlefield and Nash, 2008). As stated earlier, the village is located approximately 10 kilometres away from its nearest town as well as the nearest railway station and 4 kilometres from the nearest bus stop. The 4 kilometres-long approach road is unmetalled, and there is no provision of public transport. To reach the bus stop villagers have to cross this 4-kilometres unmetalled road. The only means of covering this distance are cycle, bike or simply on foot. It becomes very difficult for women, especially for mothers, to commute this long stretch. They have to balance both household responsibilities and workspace 
liabilities (Johansson et al., 2003; Turner and Niemeier, 1997). For all these constraints, women prefer to work near their residence (Champion et al., 2009; Chandrasekhar and Sharma; Barker and Connolly, 2006; Moss et al., 2004; McKenzie and Rapino, 2011). Except one, all women were found to commute within 10 kilometres of radius.

\section{Occupational Profile}

Commuter's occupation is a significant alliance of commuting pattern because all commuters have been linked primarily to the availability and nature of work (Champion et al., 2009). This study involved only the working commuters who commute for their main work throughout the year. It was found that all commuters commute only for non-farm works. Non-farm work, in this paper, is defined to exclude agriculture, forestry, fisheries but to include trade and processing of these products in addition to other goods and services, included as secondary, tertiary (Coppard, 2001:7), quaternary or quinary activities. ${ }^{8}$ Farm-based activities offer jobs within the village and thus farm workers' day-to-day mobility is confined within the villageboundary. Non-farm works, on the other hand, pull workers to developed villages and urban areas where the agglomerations of these works are more. This finding is in line with earlier researchers (Krishnamurty, 1984; Lanjouw and Lanjouw, 2001; Himanshu and Stern, 2011) who opine that access to non-farm works increases people's mobility. Although these workers account for only $1 / 5$ th of the total main workforce in the village but their proportion in the non-farm sectors of work (main) remains quite significant i.e. more than $71 \%$. Either other non-farm jobholders who are noncommuter by nature have settled their jobs within the village or are permanent migrants or are circular migrants.

\footnotetext{
${ }^{8}$ Quinary activity lies at the top most layer of quaternary activities. It includes chief executives in government and non-government organisations, planners, professional consultants, legal advisors, researchers, scientists, etc. Workers involved in quinary activities are often labeled as gold-collar workers (Hartshorn and Alexander, 2002:2).
}

Commuters are employed both in the organised and unorganised sectors of non-farm work. In fact, majority of them are in the unorganised sectors of jobs. Their proportion is more than $50 \%$ higher than the organised sector jobholders are. Number of commuters employed in the organised sectors of work is meagre- only around $1 / 4$ th of the total commuters. They are all in different government, co-operative, trusts and large private enterprises. Their average earning exceeds those who are in the unorganised jobs. The unorganised jobholders were found to belong to two broad groups - self-employed and paid workers, also known as wage labourers. About $63 \%$ of commuters of the unorganised sector are employed as paid workers. They work in different shops, trade houses, garages, husking mills and in small factories located in Paharhati, Satgachhia, Shankarpur, Debpur more, ${ }^{9}$ Radhakantapur and at Memari (Figure 1). Remaining $37 \%$ of the commuters of this unorganised sector are selfemployed as shopkeepers, photographers, pathologists, physicians, vegetable vendors and car drivers, and so on. All these jobs have grown to satisfy the local needs.

It was found that commuters' work status has a close relation with possession of agricultural land. Farm-income, here, plays a very important role to access remunerative nonfarm work. Those who are having large landholdings have invested their surplus-farm income for their siblings' higher education without involving them in earning at an early age. Influence of household income on attainment of siblings' education has been researched earlier (Sikdar and Mukherjee, 2012; Blanden and Gregg, 2004; Filmer and Pritchett, 1999; Taubman, 1989; Graaf, 1986). These researches say that dropouts from schools are high among households with financial constraints. Higher educated people have found remunerative jobs. Sometimes surplus farm-income has been invested to establish self-employment businesses like

\footnotetext{
${ }^{9}$ More, in Bengali, is often used to present the junction of two roads.
} 
setting up a jewellery shop or establishing a studio or a pathological laboratory, which require high initial costs but not necessarily higher education. Himanshu and Stern (2011:16) also noted the influence of farmincome on non-farm job in their empirical study in Palanpur, a small village of Moradabad District in Uttar Pradesh. In these cases, 'commuting offers people the dual advantages of higher earnings from non-farm economic activities in urban areas keeping one foot in the farm-economy and thus reducing both the risks associated with longer-term migration, and the outgoing on food, shelter, healthcare and schooling' (Deshingkar \& Anderson, 2004:3).

This research shows that with the decrease of farm-income, the quality of non-farm job goes down. During field survey, it was known that while the son of a rich family, after passing $10+2$ class standard, went through special career trainings programmes and acquired job, another young of a poor family with same qualification slipped into poverty-driven job of vegetable-vending. In poor households, commuting provides a way of coping without graduating out of poverty. It is not possible to say that poor have become non-poor after accepting these non-farm jobs. However, such non-farm jobs are sounder than agricultural labour. There are only 4-5 households Below Poverty Line (BPL) in this commuting group whereas most of the BPL people are engaged as agricultural labourers. From the experiences of slow growth of agrarian economy, huge burden of demand from a small piece of tract and its seasonal character, they have simply slipped into non-farm works.

\section{Directions of Commute}

Commuting is the daily spatial interaction between residence and workplace. Commute directions depend on the availability of jobs. It was found that all commuters are engaged in non-farm works. The agglomeration of these works is generally more in large villages, rural service centres and towns. Being a village there are two major directions of out-commuting ${ }^{10}$ rural-to-rural ( $R-R)$ commuting and rural-tourban (R-U) commuting. Besides these two, a third category i.e. commuting to undefined direction (rural/urban) is also prevalent among few working commuters. However, $R-R$ commuting dominates over the other two. Out of the total working commuters, more than $70 \%$ commuters commute to rural areas. In fact, Memari-II Block is purely a rural Block and the village is in the amidst of villages all around. The nearest town lies at a distance of 10 kilometres. This is a class III town according to Census of India (2011). ${ }^{11}$ Long distance from the urban centre is one of the reasons for lower $\mathrm{R}-\mathrm{U}$ commuting. This evidence goes parallel to some previous researchers (Deshingkar and Anderson, 2004; Champion et al., 2009; Partridge et al., 2010) who found the decreasing trend of $\mathrm{R}-\mathrm{U}$ commuting with increasing distance from the urban area. In such cases, people of these rural areas have to be dependent on local options for their livelihood. Distance-dependent distribution of these R-R working commuters is highly skewed.

Commuters' occupation is an important parameter influencing the direction of commuting. Occupational structure of the R-R commuters is asymmetrically distributed. More than $80 \%$ of them are in unorganised sectors of non-farm work. It encompasses both the regular paid labourers and self-employees. Regular paid workers are employed in shops, garages, trade houses, husking mills and selfemployed workers are engaged as private medical practitioners, pathologists, photographers, shopkeepers, barbers, goldsmiths, etc. The first group is of unskilled

\footnotetext{
${ }^{10}$ Although commuting is a two-way process but outcommuting is used to denote commuting from a referred spatial unit outwards such as commuting from a village. Similarly, in-commuting is used to refer commuting towards a particular spatial unit such as commute flows of workers towards a town or to an industrial unit (Barker and Connolly, 2006).

${ }^{11}$ Census of India classifies urban areas based on population sizes, viz., a) Class I town/ cities: 100,000 and above, b) Class II town: 50,000-99,999, c) Class III town: 20,000-49,999, d) Class IV town: 10,000-19,999, e) Class V town: 5,000-9,999.
} 
labourers while the second group has achieved special skill to run their businesses. It was found that more than $90 \%$ of R-R commuters commute within 5 kilometres of radius of the village. The location of their jobs is a significant aspect. Debpur more, Shankarpur, Radhakantapur, Paharhati, Satgachhia are some important destinations of the commuters (Figure 1). All the labour markets are located at the junction of two roads. These are also the places where the main roads of many villages have merged with the metalled roads. Therefore, people coming from different villages assemble here to satisfy their daily needs. The intention of long commute decreases if commuters get their jobs near their residences. The R-R commuters employed in organised sectors commute for long distance.

About $23 \%$ of the commuters commute to urban areas. Among the urban destinations, Memari is the most common. $43 \%$ of the $\mathrm{R}-\mathrm{U}$ commuters are in organised jobs. The unorganised jobholders are employed in factories, shops or have their own shops. Figure 2 shows that overall rate of commuting is maximum within the distance of 5-10 kilometres. There is a sharp fall in the gradient of commuting beyond 10 kilometres of distance. After being incorporated into the local labour markets, the greatest pull is exerted by Memari town (10 kilometres). Commuters are grasped by the labour markets at Memari. Those who commute beyond 10 kilometres are all government employees. Their common destinations are Barddhaman (nearly 36 kilometres), the district headquarter and Jamalpur (17 kilometres). In literature, researchers like White (1977), Lonsdale (1966) and Dent and Bond (2008) have shown the influence of wage on commute distance. The more the wage commuters get, the more the distance they agree to commute to. A few workers commute for undefined distance. They are engaged in vending vegetables from doorto-door or driving rented car. Initiation of agrobased industries like rice mill, flourmill, oil mill, saw mill, papad-making industry, paperboardmaking industry may help to provide better job opportunities than that are now. The large villages, which are connected by metalled roads such as Paharhati, Satgachhia, Shankarpur, Radhakantapur, Shridharpur and Amadpur (Figure 1), are some suitable places for these establishments.

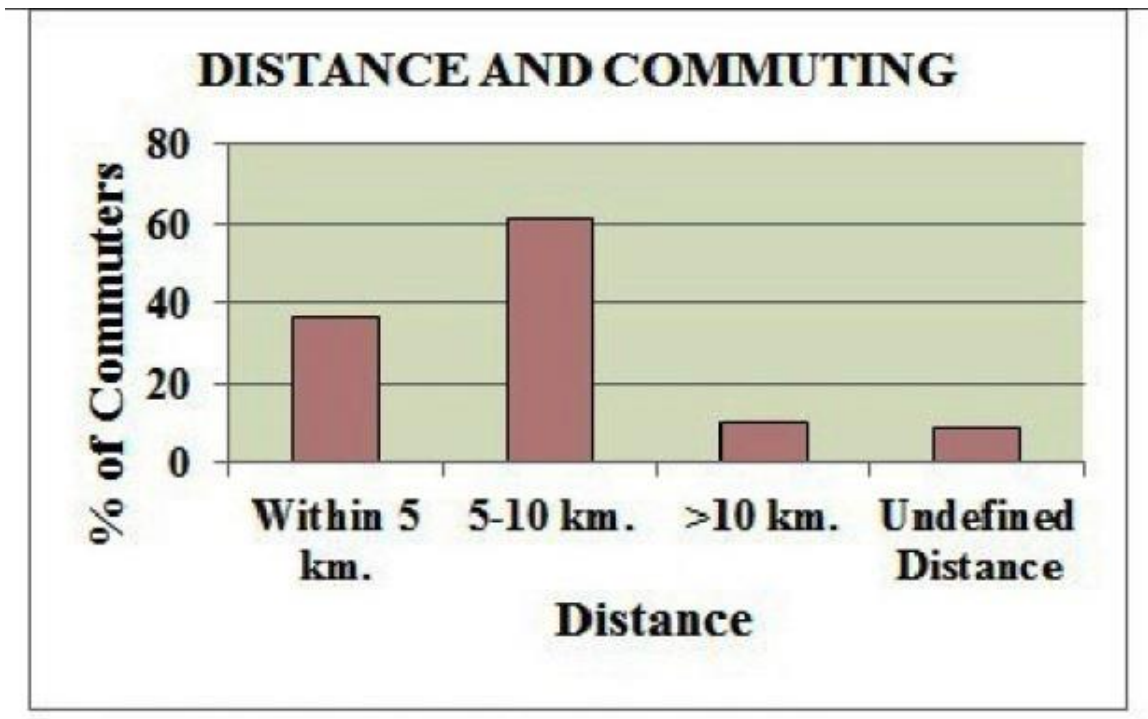

Fig. 2: Rate of Commuting with Distance Source: Based on Primary Data collected from Gandharbapur, 2014 


\section{Modes of Transport}

Transport is an integral part of commuting. 'Mobility requires a combination of appropriate transport infrastructure, improved transport services, and affordable means of transport, both motorized and nonmotorized' (Starkey et al., 2002: IV). Transport makes daily journey-towork possible. There is a positive relation between transport network density and the rate of commuting (Partridge et al., 2010). In this village, there is no provision of public transport. As mentioned earlier, villagers have to cross minimum 4 kilometres of distance through unmetalled road to reach the metalled road from where they can avail public transport. Mainly to cover these 4 kilometres of distance daily, all commuters have to keep private vehicles. The two most widely used and popular vehicles are bicycle and bike. Even those, who depend on break-journeys, ${ }^{12}$ use either bicycle or bike as their first mode of transport. Transit type determines timedistance and commute costs. Bicycle, being a cheap vehicle, is most commonly used mode of transport. It is available in almost every household. More than $55 \%$ of the commuters use bicycle as their only mode of transport (Figure 3).

$30 \%$ of the commuters use only bike. $10 \%$ of the working commuters practise breakjourneys. The decision whether one will select bicycle or bike does not depend on the distance to be covered. Selection of vehicle depends on economic background of the family as well as their job-status. It came into focus that while some commuters use bikes for covering 5 kilometres of distance on one way, there are many commuters who use bicycle for covering 10 kilometres of distance on single direction. Nearly $90 \%$ of the commuters who use bikes as their only mode of transport, belong to rich agrarian families. Their economic surplus has helped them to commute by bikes. Related to this context, Murakami and Young (1997) noted that low income people are less likely to own a costly vehicle because maximum of their

\footnotetext{
${ }^{12}$ Break journey is the combination of several journeys with breaks between two consecutive journeys.
}

income are consumed on food and housing. Such vehicles not only include initial purchasing cost but it also adds recurring cost for fuel. At the same time, job-status is also an important parameter. Most of the government employees use bike as their principal mode of transport. To some of them, bike is the symbol of status and adventure. Transit type determines time distance. Time-distance is an important issue in development theory. Different modes of transport cause differences in the timedistance. Bicycle is a muscle-driven, much slow vehicle. It has been found that to cover 10 kilometres, a cyclist takes about $1 \mathrm{hr}$. while a biker takes only 25 minutes and thus saves 35 minutes. One, who invests more time in commuting, gets less productive hours.

Rural transport is viewed as a fundamental part of rural development programmes. With the aim to develop transport network in rural India, a number of government-aided projects were initiated. As stated earlier, PMGSY is such a project, which aims to connect the unconnected rural inhabitants through allseason roads, making them paved. It was launched in 2000. However, still in 2015, the main road of the village is still made of morum $^{13}$ soil. The absences of good road and public transit have created anxiety and frustration among the villagers, especially among the women because women are more dependent on public transit than men are (White, 1977; Tiwari, 2014; Anand and Tiwari, 2007). Reduced accession to public transport lowers down people's willingness to commute (Deshingkar and Anderson, 2004; Coppard, 2001). After maintaining both home and work, it is very difficult for women to cover 8 kilometres (back and forth) daily by walking or cycling. In this context, a 50-year old woman narrated her feelings.

I am single. I stay alone. I have 5 bighas (1 bigha $=20$ kathas $=$ nearly 1333 sq. metres) of agricultural land. I depend on sharecroppers. At this, I can easily sustain but I feel lonely. I learnt knitting. I could join in any ladies tailor centre at

\footnotetext{
${ }^{13}$ Morum is a hard, red lateritic soil.
} 
Memari but how will I go daily? I do not know cycling. It is not possible for me to walk daily. However, if I could commute, I would get an association, a work for me and I would feel happy. (Pranati Mondal, ${ }^{14}$ Gandharbapur, 2014)

Absence of public transport constrains women's mobility. Pranati Mondal wants to get involved in work. She desires this not for her economic sustenance but for a lively living. Commuting may become a reliever of her isolation, bringing her closer to other people, making possible wider socialisation, and even allowing her to utilise the free time. Thus, it may help her to live delightfully and at the same time, her work may make her a valuable resource in the society. However, nonavailability of public transit restricts her movement and pushes her to carry a bored, lonely life. Pranati Mondal could escape commuting because she is with good financial background but those women who are not with this assurance; they have to leave the village, even keeping their helpless dear one at home. Archana Bag (40 years), a migrant stated her situation.

This year I have lost my husband. Now there are two members in my family-my old mother-in-law and me. We have no land. I have taken a job of cooking in a nursing home at Memari. For this, I need to go early in the morning and come back late in the evening. There is no provision of public transport. I do not know cycling. Who will help me to go and come back daily? That is why I have to stay in a rented house at Memari leaving my old mother-in-law at home. If there would be public transport facilities then it would be helpful both for me and my mother-in law. (Archana Bag, Gandharbapur, 2014)

Those women, who commute for work, have learnt the art of either cycling or bike riding.

\footnotetext{
${ }^{14}$ All interviewees' names used in this article are fictitious.
}

Susweta (34 years) is such a commuter. She narrated her experiences.

I have to cover nearly 20 kilometres daily to reach my school. I depend on my cycle to cross this 4 kilometres of morum road. I was not accustomed to drive cycle for this long stretch before marriage. I feel very tired after returning home. I have a little daughter. I cannot give her much time. However, the members of my family are very cooperative and understanding. They manage everything. (Susweta, Gandharbapur, 2014)

Although the absence of public transport affects women's mobility much more than men, some men commuters also face this problem. Dilip Karmakar (64 years) who is a cardiac patient states about the need of paratransit in the villages.

Recently I had a serious cardiac attack. After taking rest for three consecutive months, now I have returned back to my working life. However, my physician has suggested me not to ride a bike or bicycle at this right moment. Therefore, I have hired an assistant. He takes me regularly to my trade house in Shankarpur and reaches me again at my home. I do not know for how many days he will do this job. Often I think if there would be provision of paratransit in the form of jeep, trekker, ${ }^{15}$ auto-rickshaw or toto, ${ }^{16}$ I could move independently. Even persons like me would be benefitted. Absence of any paratransit is the most serious problem in our village, I think. (Dilip Karmakar, Gandharbapur, 2015)

Paratransit as a feeder for mass transit may turn the vicious cycle of insufficient transport in rural areas. The needy women may commute

\footnotetext{
${ }^{15}$ Trekker is quite like a jeep. 12-16 passengers can travel at a time. It is fueled by diesel.

${ }^{16}$ Toto is a battery-operated eco-friendly paratransit with zero emission, also known as e-rickshaw or green autorickshaw. It provides seating arrangement for 4 to 8 passengers.
} 
easily. It may be a way for poverty reduction, women's empowerment and for a number rural development policy. It is a low capital-intensive solution. It can help commuters on fixed-route as line-haul operator as well as commuters may hire them for their purposes at relatively low fare (Tangphaisankun et al., 2009).

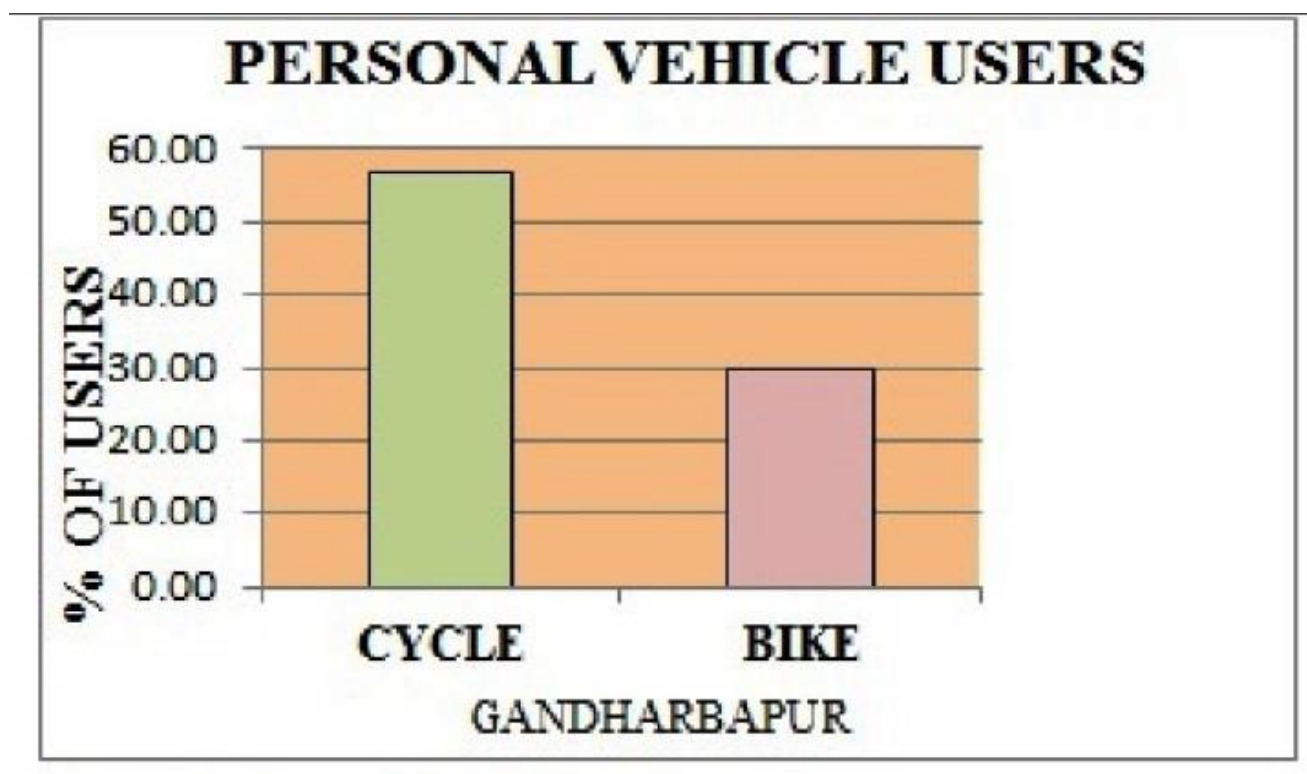

\section{Fig. 3: Personal Vehicle Users \\ Source: Based on Primary Data, 2014}

\section{Commute Time}

Commute time is a significant parameter in studying commute pattern. It shows how much time a commuter invests to access work. It also affects their physical and mental health, their productivity in their workspaces as well as at home. In this article, three significant findings were identified regarding commute time. First, although commute time is positively correlated to absolute spatial distance, there are some exceptions of this trend. As the distance from home to work increases, commute time also increases and vice-versa. However, there are some discrepancies of this general finding. Even when the distance is constant for all, some commuters differ by time. It is because of the role of the mode of transport. Those who use bicycle, take much time to reach the same distance than those who drive bike. This finding resembles to Shen (2007), Carr (2008) who also noted the influence of mode of transport on commute hours. Now selection of mode of transport between a bike and a cycle depends upon per capita household income. It has been found that to commute 4 kilometres (on one way) when one drives bike, another person drives cycle to commute 10 kilometres (on one way). In this case, the former belongs to a rich farmers' household. Besides his non-farm job, there is supply of farm income in their household while the latter is the household head. Although he is engaged in a same status non-farm work, he does not enjoy additional income from farming. Hence, per capita household income is a major determinant of selection of mode of transport surpassing job status or distance to work. Evelyn et al. (2003), in a research on transport of low-income Californian people, also found influence of economy on selection of mode of commute.

Secondly, as commute time increases, the number of commuters reduces. More than $60 \%$ commuters invest 30 minutes on one way. As the commute time increases to 60 minutes (on one way), number of commuters suddenly drops to below $20 \%$. This decreasing trend of number of commuters with increasing time is quite consistent to (Beige, 2012; McKenzie and Rapino, 2011; Clark et al. 2003). 
Thirdly, it was found that the long-time commuters (those who commute for more than 1 hour on one way) are all government employees. Their monthly earning is much higher than average commuters earn. Their job status and higher wages support them to commute long (White, 1977; Dent and Bond,
2008; Lonsdale, 1966; Beige, 2012). On the other hand, to avoid the costs of commuting, low-income people migrate near their workplaces. Commuters earning more spend more time on commuting than low-earning commuters (Barker and Connolly, 2006).

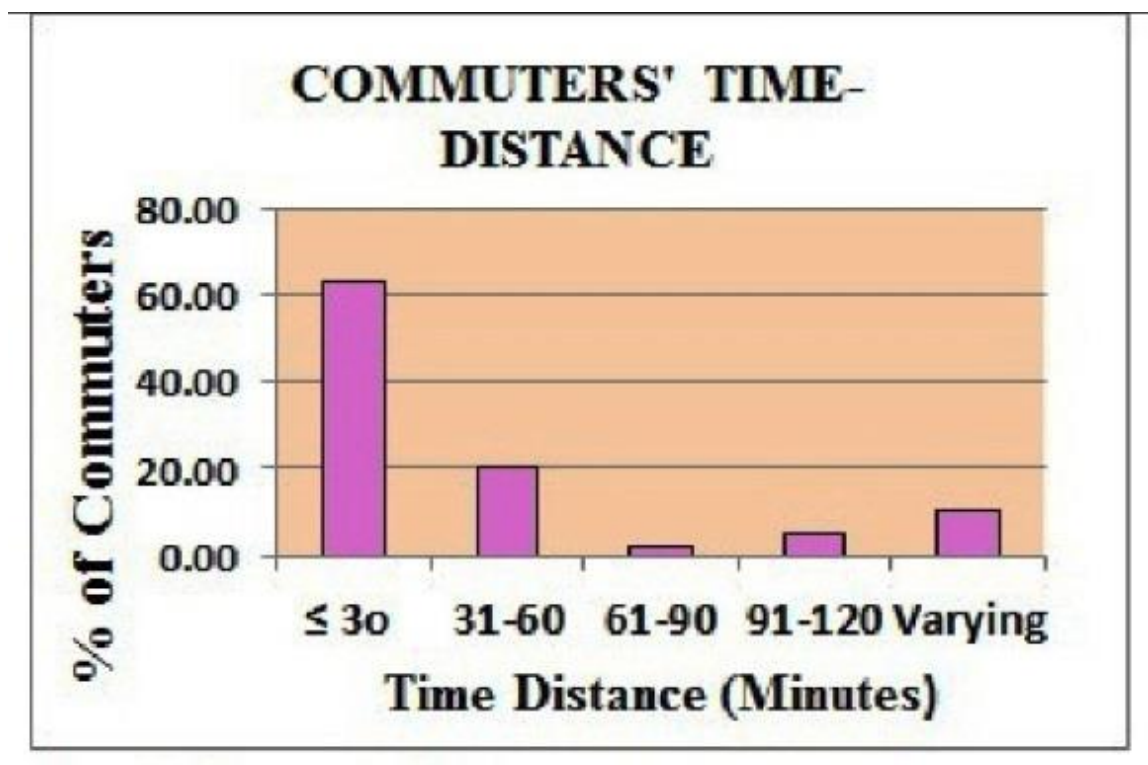

\section{Fig. 4: Commute Time \\ Source: Based on Primary Data collected from Gandharbapur, 2014}

\section{Conclusion}

'Mobility is undoubtedly a crucial aspect of accessing and retaining employment for working rural dwellers. From a rural development policy perspective, measures designed to enhance the mobility of rural dwellers are therefore a priority' (Moss et al., 2004: 121). It may help to reduce the burden on agriculture. Rural people may access urban jobs, even living in villages. Over-urbanisation will also be reduced. This empirical study shows that all commuters commute for non-farm work. These workers belong to two broad groups. The first group possess large land holdings and they have invested their surplus farm income for remunerative non-farm jobs. The second group consists of landless poor and marginal farmers. To escape poverty they have slipped into non-farm jobs. Their non-farm jobs are not at all remunerative. Therefore, the influence of farm-income cannot be overlooked even during selection of non-farm jobs. It cannot be stated that poor have become nonpoor after selecting these non-farm jobs. However, they are in a better position than those of the agricultural labourers. The concentration of BPL households is more among agricultural labourers than among these commuters. Thus, how much income mobility ${ }^{17}$ of rural poor is caused by this occupational mobility ${ }^{18}$ for which they

\footnotetext{
${ }^{17}$ Income mobility is one type of vertical forms of mobility in which one's income changes (either decreases or increases) between two refereed points of time (Jantti and Jenkins, 2013).

${ }^{18}$ Occupational mobility refers to the shifting of occupations or simply of jobs from one job to another (Moscarini and Thomson, 2007). It may be intergenerational as well as intra-generational occupational mobility.
} 
commute outside the village may be an issue for further research.

The more the employment opportunities there are nearby and the less the in-situ jobs available in an area, the more will be outcommuting. This trend is accelerated by the ability of the people to perform those works and the connecting medium to maintain this daily oscillation. According to Parida and Madheswaran (2010:1), 'mobility is one of the important aspects of human nature, which is often guided by socioeconomic, political as well as environmental factors'. Hence, transport lines have a crucial role for the development of the labour markets and to make those labour markets accessible. During primary data collection, it was found that there is potential field of commuters among women. Some of them really want to commute to maintain both their family and financial sustainability, some for having a pleasant living. However, the absence of all-weather good road and nonavailability of any public transit limits their mobility. Absence of public transit, even in the form of paratransit costs a lot to the commuters, especially who are ill, aged or physically weak. This research points to the role of transport in mobility studies for future research agenda. Direct connectivity with the town may change the existing commuting pattern of this village making people economically sound and socially sustained.

\section{References}

Anand, A. and G. Tiwari (2007). A Gendered Perspective of the Shelter-Transport-Livelihood Link: The Case of Poor Women in Delhi, Transport Reviews: A Transnational Transdisciplinary Journal, 26 (1), February, pp. 63-80.

Barker, L. and D. Connolly (2006). Long Distance Commuting in Scotland, Scottish Executive Social Research, Transport Research Series, July, available at: www.scotland.gov.uk/ (accessed 11 September 2014 at 09:12:19 hrs).

Beige, S. (2012). Analyses of Commuting Distances and Times in the Household Context: The Case of Berlin, 13th International Conference on Travel Behaviour Research,
Toronto, July 15-20, available elib.dlr.de/ (accessed 5 April 2014 at 11:21:17 hrs).

Blanden, J. and P. Gregg (2004). Family Income and Educational Attainment: A Review of Approaches and Evidence for Britain, Oxford Review of Economy Policy, 20 (2), pp. 245-263.

Carr, K. (2008). Qualitative Research to Assess Interest in Public Transportation for Work, Journal of Public Transport, 11 (1).

Census of India (2011). Office of the Registrar General and Census Commissioner, Ministry of Home Affairs, Government of India.

Champion, T., M. Coombes, and David L. Brown (2009). Migration and Longer-Distance Commuting in Rural England, Regional Studies, 43(10), 1245-1259, December, Routledge, Taylor \& Francis Group.

Chandrasekhar, S and A. Sharma. Does Spatial Distribution of Economic Activities Influence Commuting Choices of Workers? Evidence from India, available at https://www.conftool.com/.../SharmaDoes_Spatial_Distribution_of_Eco...(accessed 18 December 2013 at 16:37 hrs).

Chandrasekhar, S. (2011). Workers Commuting Between the Rural and Urban: Estimates from NSSO Data, Economic and Political Weekly, Nov. 12 , XLVI (46) pp. 22-25.

Chen, Xuwei, F. Benjamin Zhanbc \& Guangyu Wu (2010). A Spatial and Temporal Analysis of Commute Pattern Changes in Central Texas, Annals of GIS, 16 (4), pp. 255-267.

Clark, William A.V., Youqin Huang and Suzanne Withers (2003). Does Commuting Distance Matter? Commuting Tolerance and Residential Change, Regional Science and Urban Economics, 33, pp. 199-221, Elsevier.

Coppard, D. (2001). The Rural Non-Farm Economy in India: A Review of the Literature, Report No. 2662, Natural Resource Institute, November, available at: projects.nri.org/rnfe/pub/papers/2662.pdf (accessed 18 May 2014 at 12:31:22 hrs).

Dent A. and S. Bond (2008). An Investigation into the Location and Commuting Patterns of 
Part-Time and Full-Time Workers in the United Kingdom, using Information from the 2001 Census, Office for National Statistics, available at: www.neighbourhood.statistics.gov.uk/ (accessed 8 July 2014 at 19:12:17 hrs).

Deshingkar, P. and E. Anderson (2004).People on the Move: New Policy Challenges for Increasingly Mobile Populations, Natural Resource Perspectives, 92, June, Overseas Development Institute, available at: www.odi.org/resources/docs/72.pdf (accessed 13 May 2014 at 12:28:53 hrs).

Deshingkar, P. (2010). Migration, Remote Rural Areas and Chronic Poverty in India, Working Paper 323, Overseas Development Institute, available at: www.chronicpoverty.org/uploads/...files/WP16 3\%20Deshingkar.pdf (accessed 3 December 2014 at 12:57:48 hrs).

Dickinson, Robert E. (1957). The Geography of Commuting: The Netherlands and Belgium, Geographical Review, 47, pp. 521-538.

Blumenberg, Evelyn, Douglas Miller, Mark Garrett, Lisa Schweitzer, Karen Kitsis, Michael Manville and Bravishwar Mallavarapu (2003). California Transportation Needs Assessment: The Transportation Barriers and Needs of Welfare Recipients and Low-Wage Worker, Community Service Projects/Papers, The Ralph and Goldy Lewis Center for Regional Policy Studies, UCLA School of Public Affairs: UC Los Angeles.

Filmer, D. and L. Pritchett (1999). The Effect of Household Wealth on Educational Attainment: Evidence from 35 Countries, Population and Development Review, March 25(1), pp. 85- 120.

Graff, P. M. De (1986). The Impact of Financial and Cultural Resources on Educational Attainment in the Netherlands, Sociology of Education, 59 (4), October, pp. 237-246.

Harris, S., A. Alasia and Ray D. Bollman (2008). Rural Commuting, Statistics Canada Perspectives, Catalogue No. 75-001-X, November, pp. 13-21, available at:www.statcan.gc.ca/pub/ (accessed 14 July 2014 at 10: $35 \mathrm{hrs})$.
Hartshorn, Truman A. and John W. Alexander (2002). Economic Geography, Third Edition, New Delhi: Prentice Hall of India Private Limited (ISBN: 81-203-0519-1).

Higgins, C., L. Duxbury and K. Lea Johnson (2000). Part Time Work for Women: Does it really help Balance Work and Family?, Human Resource Management, Spring, 39(1), pp. 1732.

Himanshu and Stern, N. (2011). India and an Indian Village: 50 Years of Economic Development in Palanpur, Working Paper 43, London School of Economics, Asia Research Centre, April.

Jantti, M. and S. P. Jenkins (2013). Income Mobility, Discussion Paper No. 7730, November, Institute for the Study of Labor, IZA, available at: http://ftp.iza.org/dp7730.pdf (accessed 19 May 2015 at 12:35 hrs).

Johansson, B., J. Klaesson and M. Olsson (2003). Commuters' Non-Linear Response to Time Distances, Journal of Geographical Systems, Springer-Verlag, 5, pp. 315-329.

Klis, M. van der and Clara H. Mulder (2008). Beyond the Trailing Spouse: The Commuter Partnership as an Alternative Family Migration, J Hous \& the Built Ennviron, 23, Springer, pp. 119.

Krishnamurty, J. (1984). Changes in the Indian Workforce, Economic and Political Weekly, XIX (50), December 15, pp. 2121-2128.

Kundu, A. (2009). Exclusionary Urbanisation in Asia: A Macro Overview, Economic and Political Weekly, November 28, XLIV (48), pp. 48-58.

Lanjouw, J. O. and P. Lanjouw (2001). The Rural Non-Farm Sector: Issues and Evidence from Developing Countries, Agricultural Economics, 26, pp. 1-23, Elsevier.

Littlefield, M. and A. Nash (2008). Commuting Patterns as at the 2001 Census and their Relationship with Modes of Transport and Types of Occupation, Office for National Statistics, available at: http://www.neighbourhood.statistics.gov.uk/ (accessed 09 September 2014 at 13:45:36 hrs). 
Lonsdale, Richard E. (1966). Two North Carolina Commuting Patterns, Economic Geography, 42 (2), April, pp. 114-138, Clark University.

Mahbub A.Q.M. (1997). Mobility Behaviour of Working People in Bangladesh-Rural-Rural and Rural-Urban Circulation, University of Dhaka: Urban Studies programme (ISBN: 984-510-012$0)$.

Mathew, S. Susan (2012). Distress Driven Employment and Feminisation of Work in Kasargod District, Kerala, Economic and Political Weekly, June 30, XLVII (26-27), pp. 65-73.

McKenzie, B. and M. Rapino (2011). Commuting in the United States: 2009, American Community Survey Reports, ACS-15. U.S. Census Bureau: Washington, DC, available www.census.gov/prod/2011pubs/acs-15.pdf (accessed 06 November 2014 at 15:45:47 hrs).

Mehrotra, S., A. Gandhi and B. K. Sahoo (2012). Organised and Unorganised Employment in the Non-Agriculture Sectors in the 2000s, Occasional Paper No. 6/2012, April, Institute of Applied Manpower Research, Planning Commission, Government of India, available at: www.iamrindia.gov.in/organised-

unorganised.pdf (accessed 02 December 2014 at 11:10 hrs).

Morrill, R., J. Cromartie and G. Hart (1999). Metropolitan, Urban, and Rural Commuting Areas: Toward a Better Depiction of the United States Settlement System, Urban Geography, 20 (8), pp.727-748.

Moskarini, G. and Kaj Thomsson (2007). Occupational and Job Mobility in the US, Scand. Journal of Economics, 109 (4), pp. 807-836.

Moss, J. E., C. G. Jack and M. T. Wallace (2004). Employment Location and Associated Commuting Patterns for Individuals in Disadvantaged Rural Areas in Northern Ireland, Regional Studies, 38 (2), pp. 121-136, Routledge.

Murakami, E. and J. Young, (1997). Daily Travel by Persons with Low Income, Paper for NPTS Symposium, Betheda, MD, October 29-31, Available nhts.ornl.gov/1995/Doc/lowinc.pdf (accessed 05 November2014 at 20:58:05 hrs).
National Commission for Enterprises in the Unorganised Sector/NCEUS (2007). Report on Conditions of Work and Promotion of Livelihoods in the Unorganised Sector, available http://nceuis.nic.in/ (accessed 1 July 2008 at 14:20 hrs).

Ommeren, V., P. Rietveld and P. Nijkamp (1997). Commuting in Search of Jobs and Residences, Journal of Urban Economics, 42, pp. 402-421.

Parida, J. Krshari and Madheswaran, S. (2010). Spatial Heterogeneity and Population Mobility in India, Working Paper 234, The Institute for Social and Economic Change, available books.google.com/(accessed 16 May 2014 at 18:14:22 hrs).

Partridge, M. D., Md. K. Ali and M. R. Olfert (2010). Rural-to-Urban Commuting: Three Degrees of Integration, Growth and Change, 41 (2), June, pp. 303-335.

Pittsburgh Downtown Partnership (2010). Living, Working and Commuting, Pittsburgh PA 15222, available at: www.downtownpittsburgh.com (accessed 18 September 2014 at 14:45 hrs).

Pradhan Mantri Gram Sadak Yojana (2015). Ministry of Rural Development, Government of India, available at pmgsy.nic.in (accessed 10 February 2015 at 20:10 hrs).

Punpuing, S. (1993). Correlates of Commuting Patterns: A Case-study of Bangkok, Thailand, Urban Studies, 30 (3), pp. 527-545, SAGE.

Reardon, T., K. Stamoulis and P. Pingali (2007). Rural Nonfarm Employment in Developing Countries in an Era of Globalization, Agricultural Economics, Issue Supplement 1, pp. 173-184, Wiley Online Library.

Reddy, B. Sudhakara and P. Balachandra (2012). Urban Mobility: A Comparative Analysis of Megacities of India, Transport Policy, 21, April, pp. 152-164, Elsevier.

Renkow, M. and D. Hoover (2000). Commuting, Migration and Rural-Urban Population Dynamics, Journal of Regional Science, 40 (2), pp. 261-287. 
Sabapathy, A., P. G. Flachsbart and S. Saksena (2012). Commuting Patterns of Employees in the Information Technology and Traditional Manufacturing Sectors of Bangalore, India, Transport Policy, 19 (1), January, pp. 155-166, Elsevier.

Shen, Q. (2007). Spatial and Social Dimensions of Commuting, Journal of the American Planning Association, 66 (1), pp. 68-82.

Shirgaokar, M. (2014). Employment Centers and Travel Behavior: Exploring the Work Commute of Mumbai's Rapidly Motorizing Middle Class, Journal of Transport Geography, 41, December, pp. 249-258.

Sikdar, S. and A. N. Mukherjee (2012). Enrolment and Dropout Rate in School Education, Economic and Political Weekly, XLVII (1), 7January, pp. 27-31.

Skeldon, R. (1984). Migration in S. Asia: An Overview, Population Research Leads, No.16, Population Division, ESCAP, Bangkok.

Srinivasan, K., P. Bhargav, G. Ramadurai, V. Muthuram and S. Srinivasan (2007). Determinants of Changes in Mobility and Travel Patterns in Developing Countries: Case Study of Chennai, India, Transportation Research Board, Journal of the Transportation Research Board 2038 (1), pp. 42-52.

Srivastava, N. and R. Srivastava (2009). Women, Work and Employment Outcomes in Rural India, IFAD, available at: www.fao-ilo.org (accessed 11 September 2014 at 09:12:11 hrs).

Starkey, P., S. Ellis, J. Hine and A. Ternell (2002). Improving Rural Mobility-Options for Motorized and Nonmotorized Transport in Rural Areas, Technical Paper No. 525, World Bank, Washington D.C.

Statistics New Zealand. Workforces on the Move: Commuting Patterns in New Zealand, available

www.stats.govt.nz/commuting/workforce-on-

the-move.pdf (accessed 22 May 2014 at 18:00 hrs).

Stutzer, A. and S. Bruno Frey (2007). Commuting and Life Satisfaction in Germany, Information zur Rumenwicklung, Heft, available at:www.bsfrey.ch/articles/456_07.pdf

(accessed 22 February 2013 at 11:43:27 hrs).

Tangphaisankun, Akkarapol, Fumihiko Nakamura and Toshiyuki Okamura (2009). Influences of Paratransit as A Feeder of Mass Transit System in Developing Countries Based on Commuter Satisfaction, Journal of the Eastern Asia Society for Transportation Studies, 8.

Taubman, P. (1989). Role of Parental Income in Educational Attainment, The American Economic Review, 79 (2), Papers and Proceedings of the Hundred and First Annual Meeting of the American Economic Association, May, pp. 57-61.

Tiwari, G. (2014). Planning and Designing Transport Systems to Ensure Safe Travel for Women, Discussion Paper No. 2014-04, International Transport Forum, OECD, available at:

www.internationaltransportforum.org/jtrc/.../D P201404.pdf (accessed 07 May 2015 at 13:04 hrs).

Tiwari, P. and T. Kawakami (2001). Modes of Commuting in Mumbai: A Discrete Choice Analysis, The Applied Regional Science Conference (ARSC), Blackwell Publishers Ltd., UK and USA, 13 (1), March, pp. 34-45.

Turner, T. and D. Niemeier (1997). Travel to Work and Household Responsibility: New Evidence, Transportation, 24 (4), pp. 397-419, Springer, Netherlands.

Vaidyanathan, A. (1986). Labour Use in Rural India-A Study of Spatial and Temporal Variations, Economic and Political Weekly, XXI (52), 27 December, pp. A130-A146.

White, Michelle J. (1977). A Model of Residential Location Choice and Commuting by Men and Women Workers, Journal of Regional Science, 17(1), pp. 41-52.

\section{Acknowledgements}

The author is thankful to Professor Gopa Samanta, Department of Geography, The University of Burdwan and the supervisor of the ongoing research from which the idea of the article has been developed, for her valuable 
suggestions and critical comments on the draft article. The author expresses her sincere gratitude to the anonymous reviewers for their thoughtful critical comments in improving the article. 